\title{
THE EFFECT OF Anredera cordifolia (Ten.) Steenis SUPPLEMENTATION ON UTERINE INVOLUTION PROCESS EVALUATED BY OESTRUS POST PARTUM BEHAVIOR AND FERNING
}

\author{
R. Purwasih, E.T. Setiatin and D. Samsudewa \\ Faculty of Animal and Agricultural Sciences, Diponegoro University, \\ Tembalang Campus, Semarang 50275, Central Java - Indonesia \\ Corresponding E-mail : rita.purwasih@yahoo.com \\ Received January 06, 2014; Accepted Fabruary 27, 2014
}

\begin{abstract}
ABSTRAK
Tujuan penelitian ini adalah untuk mengetahui pengaruh pemberian suplementasi Anredera cordifolia (Ten.) Steenis terhadap proses involusi uterus pada kelinci. Rancangan penelitian yang digunakan adalah rancangan acak lengkap dengan 4 perlakuan dan 3 kali ulangan (T0 $=$ tanpa pemberian suplementasi Anredera cordifolia ; TI = pemberian suplementasi Anredera cordifolia 2 hari sebelum partum; T2 = pemberian suplementasi Anredera cordifolia 2 hari setelah partum; T3 = pemberian suplemantasi Anredera cordifolia 2 hari sebelum sampai dengan 2 hari setelah partum). Hasil penelitian menunjukan bahwa pemberian suplemantasi Anredera cordifolia dapat mempercepat berahi post partum pada kelinci, ditandai dengan terjadinya perubahan tingkahlaku dan gambaran ferning lendir saliva dan lendir serviks. Perlakuan terbaik adalah T3, empat hari pemberian suplementasi Anredera cordifolia masing masing sebanyak 0,45 gr/kg bobot badan/hari. Diperlukan penelitian mengenai dosis optimal pemberian suplementasi Anredera cordifolia (Ten.) Steenis yang tepat dalam memepercepat involusi uterus.
\end{abstract}

Kata kunci : Anredera cordifolia, berahi post partum, ferning, involusi uterus, tingkahlaku

\begin{abstract}
The aim of this study was to determine the effect of Anrederacordifolia (Ten.) Steenis supplementation on uterine involution process in rabbit. The research design applied was completely randomized design with 4 treatments and 3 replications $(\mathrm{T} 0=$ without Anredera cordifolia supplementation; $\mathrm{TI}=$ Anredera cordifolia supplemented two days before parturition; $\mathrm{T} 2=$ Anredera cordifolia supplemented two days after parturition; T3 = Anredera cordifolia supplemented two days before until two days after parturition). The results showed that Anredera cordifolia (Ten.) Steenis supplementation could accelerate post partum oestrus in does that were characterized by post partum oestrus behavior, ferning of saliva and cervical mucus. The best treatment was T3, that was four days Anredera cordifolia supplementation that was administered at $0.45 \mathrm{~g} / \mathrm{kg}$ of body weight/day. Further research was needed to find an optimal dose of Anredera cordifolia (Ten.) Steenis on uterine involution.

Keywords: Anredera cordifolia, post partum oestrus, ferning, uterine involution, behavior
\end{abstract}

\section{INTRODUCTION}

Rabbit is a meat producer to support meat supply. Rabbit has short gestation periods and oestrus post partum, rapid sexual maturity, and prolific (Setiaji et al., 2013). During post partum period, female rabbit or doe would undergo a process of uterus involution. In addition, there are also injuries caused by the release of placenta, in which the wound is easily contaminated by a various organisms, so that would prolong the process of healing in the uterus. The slower uterine involution the longer ovaries activities occur. Therefore, the next oestrus cycles would be delayed (Tambing et al., 2001).

One of the traditional medicines used for human that could heal wound after parturition is Anredera cordifolia (Manoi and Ballitro, 2009). Chemical contents of Anredera cordifolia are flavonoids, alkaloids, saponins, triterpenoids (Astuti et al., 2011). Dose application of Anredera cordifolia depends on the level of injuries. 
Usually, women who had delivered a baby would be treated with 7 leaves of Anredera cordifolia to heal uterine's wound. This may influence uterine involution. Therefore, a research of Anredera cordifolia supplementation on the uterine involution was carried out.

\section{MATERIALS AND METHODS}

\section{Materials}

The materials used were 12 New Zealand does, 6-7 months with the average body weight of $5 \mathrm{~kg}$, and Anredera cordifolia (Ten.) Steenis.

\section{Methods}

Individual cages, feed, and Anredera cordifolia supplementation were prepared at the beginning of the research. The dose of Anredera cordifolia supplementation was calculated based on human's formula that $50 \mathrm{~kg}$ of body weight needs 7 Anredera cordifolia leaves or similar to $22.47 \mathrm{~g}$ (single dose treatment $=0.45 \mathrm{~g} / \mathrm{kg}$ of body weight/day). First af all, Anredera cordifolia leaves were weighed, then grinded using mortar and added aquadest simultaneously to reach ratio between Anredera cordifolia leaves and aquadest at 1:3. Doe was force-drinking in the morning before feeding. Does $(n=12)$ were divided into 4 groups, namely:

T0: without Anredera cordifolia supplementation;

$\mathrm{TI}$ : Anredera cordifolia supplemented at two days before parturition;

T2: Anredera cordifolia supplemented at two days after parturition;

T3: Anredera cordifolia supplemented from two days before until two days after parturition.

\section{Parameters \\ Oestrus post partum.}

After parturition does' oestrus were observed three days at 7:00 to 7:30 a.m. Parameters observed were redness of vulva, ferning and oestrus post partum behavior.

\section{Ferning.}

Cervical and saliva mucus were taken at 7:00 to 7:30 a.m. The cervical mucus collection technique involved the use of an object glass, which was smeared in the vagina surface and allowed to dry. Saliva mucus was collected by smearing cotton bud on the bottom of does' tongue. Saliva mucus, then, smeared on object glass and allowed to dry. Ferning of cervical and saliva mucus was observed using microscope at
10 x 10 (Menaarguez et al., 2003). Ferning appeared in the microscope was scored. Scoring method of ferning was modified from both Mardiati (2003) and Suharto (2003) methods.

Ferning scoring criteria applied were $1=$ no ferning (no crystallization, just air bubbles) ; $2=$ there was ferning, small and scattered (formation of fern leaves with primary stems only); $3=$ ferning clear, and the closing $<0.5$ wide field of view (fern leaves with only a majority of primary and secondary stems, sometimes there was little tertiary branches); $4=$ ferning clear, and closing > 0.5 wide field of view (fern leaves with only a majority of primary and secondary stems, sometimes there was little tertiary branches); $5=$ ferning cover the whole field of view, but branches were short and long (fern leaves with only a majority of primary and secondary stems, sometimes there were very few tertiary branches), and $6=$ ferning cover the whole field of view and there are only long (formation of fern leaves with stems of primary, secondary, tertiary and quarterly).

\section{Data Analysis}

All data, namely oestrus post partum behaviors (Samsudewa and Capitain, 2011), color of vulva (Ball and Peters, 2004) and ferning (Noonan et al.,1975) were analyzed descriptively.

\section{RESULTS AND DISCUSSION}

\section{Oestrus Post Partum Behavior}

The lowest average frequency of oestrus post partum behaviors occurred at T0 (Table 1). This was likely caused by uterine involution process which running naturally. This indicated that doe had incomplete uterine involution which did not show receptive behavior into copulation. This occured because of hormonal factors, such as estrogen produced by internal theca of follicle de Graff cells to stimulate oestrus (WodzickaTomaszewska et al. (1991) and Hardjopranjoto (1995).

The highest average of oestrus post partum behaviors was achieved does in $\mathrm{T} 2$ followed by $\mathrm{T} 1$ (Table 1). Unfortunately, the does in T1 and T2 also did not show receptive behavior into copulation. This condition may caused by incomplete uterine involution. The result was that oestrus post partum behaviors appeared only receptive to a buck approaching, mating position, allow the buck to sniffing her and standing heat. This occurred because phytoestrogens' content in 
Table 1. Average of Oestrus Frequency of Post Partum Behavior (at 07:00 to 07:30 am)

\begin{tabular}{llllll}
\hline \multirow{2}{*}{ Behavior } & \multicolumn{5}{c}{ Treatments } \\
\cline { 2 - 5 } & T0 & T1 & T2 & T3 \\
\hline
\end{tabular}

Receptive to a buck approaching

- $1^{\text {st }}$ day observation

- $2^{\text {nd }}$ day observation

- $3^{\text {rd }}$ day observation
16

15

15

15

15

11

20

15

- $3^{\text {rd }}$ day observation

Standing heat

- $1^{\text {st }}$ day observation

- $2^{\text {nd }}$ day observation

- $3^{\text {rd }}$ day observation

Allow the buck to sniffing her

$\begin{array}{rrrr}9 & 10 & 33 & 8 \\ 8 & 11 & 11 & 8 \\ 2 & 9 & 12 & 6\end{array}$

Lordocis position

- $1^{\text {st }}$ day observation

- $2^{\text {nd }}$ day observation

0

- $3^{\text {rd }}$ day observation

18

23

15

15

19

14

13

17

16

16

16

ulation

- $1^{\text {st }}$ day observation

$\begin{array}{llll}0 & 0 & 0 & 1 \\ 0 & 0 & 0 & 0 \\ 0 & 0 & 0 & 1\end{array}$

$\mathrm{T} 0=$ without Anredera cordifolia supplementation; $\mathrm{TI}=$ Anredera cordifolia supplementation two days before parturition; $\mathrm{T} 2=$ Anredera cordifolia supplementation two days before parturition; $\mathrm{T} 3=$ Anredera cordifolia supplementation two days before until two days after parturition.

Anredera cordifolia was insufficient to speed up uterine involution.

The average frequency of oestrus post partum behaviors in $\mathrm{T} 3$ was not as much as $\mathrm{T} 1$ and $\mathrm{T} 2$, but does had lordocis position and come into copulation. Copulation occurred in the first and the third day of observation (Table 1). This condition showed that doe had completed uterine involution. In this research, time required for uterine involution was $24-72$ hours. The time was almost equivalent to the range of Tarsono et al. (2009) who stated that doe uterine involution was 48 hours post partum. The longerf treatment (in T3) affected to faster uterine involution. That condition was affected by levels of saponins, proteins and vitamin $\mathrm{C}$ which influence the 
process of healing rapid. Saponins, proteins and vitamin $\mathrm{C}$ in Anredera cordifolia gave the maximum effect to recover the reproductive organs due to the release of placenta at the end of parturition.

There was wound in the uterus during postpartum. The wound was caused by the release of the placenta during the process of partum. The process of wound healing in the uterus could be done through several stages and required some substances to help the process. Anredera cordifolia contained active substances required in the process of wound healing in the uterus, namely saponins, proteins and vitamin $\mathrm{C}$. The healing of wounds in the uterus was begun by narrowing blood vessels in the uterus. Saponins in the Anredera cordifolia were able to accelerate the narrowing of blood vessels so that no continuous bleeding in the wound. Then saponins also could stimulate the formation of collagen in the form of a cross woven to cover the wound in the uterine (Syarfati et al., 2011).

Wound healing process would be faster if the tissue nutrient needed were met. Proteins in Anredera cordifolia capable of stimulating the production of nitric oxide which could enhance blood flow carrying nutrients to every tissue in the uterus. Furthermore, the protein was also synthesized collagen so that the cell membrane would be formed (Nur, 2010). Then, it took a substance that played a role in maintaining the newly formed cell membrane. Vitamin $\mathrm{C}$ was able to maintain cell membranes, accelerate healing, increase resistance to infection, and speed healing (Almatsier, 2004).

\section{Color of Vulva}

Redness of the vulva was not found in T0, T1 but was found in T2, T3 (white-reddish) during three days' observation. Color of vulva was related to estrogen level in the blood. Increased levels of the estrogen hormone in the blood were directly proportional to the change in the color of the vulva and vagina (Hernandez et al., 2013).

Increased estrogen level in the blood would increase adrenaline level. Adrenaline would trigger the throb and the contraction of heart that can increase blood circulation. This process would lead to the depletion of the blood vessels in the vulva until vulva would be redness (Dewi et al., 2011). One of chemical content in Anredera cordifolia that affect the color of vulva is flavonoids. Flavonoids are belong to the fraction of phytoestrogens that had estrogenic activity. Phytoestrogens have similarities with natural estrogen (Sitasiwi, 2009) that affect the color of vulva.

\section{Ferning}

Ferning score of saliva in T0, T1, T2, and T3 in the first day were 1,2, 4 and 3, respectively. In the second and the third day, ferning score of saliva were 1, 2, 3 and 3 for T0, T1, T2 and T3, respectively. T0 had the lowest average score of ferning (Figure 1), it was likely caused by estrogen level in the blood that was low. The low level of estrogen in the blood affected in the absence of ferning. Dewantiningrum (2008) stated that when the doe had not oestrus, no external stimuli received by the body. Therefore, the parasympathetic nerves did not stimulate the

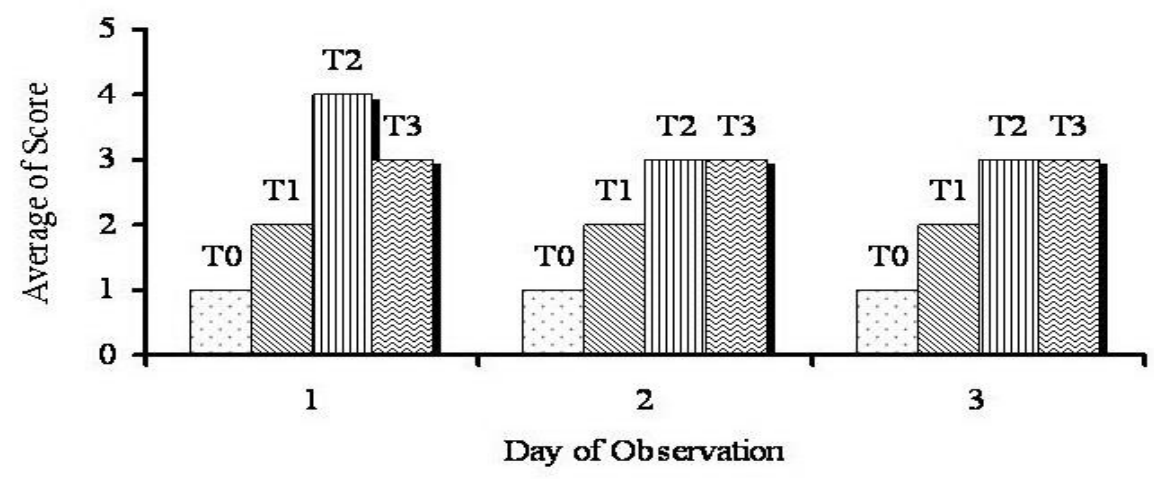

Figure 1.The graph of Ferning of Saliva. T0 $=$ without Anredera cordifolia supplementation; TI $=$ Anredera cordifolia supplementation two days before parturition; T2 = Anredera cordifolia supplementation two days before parturition; T3 = Anredera cordifolia supplementation two days before until two days after parturition. 


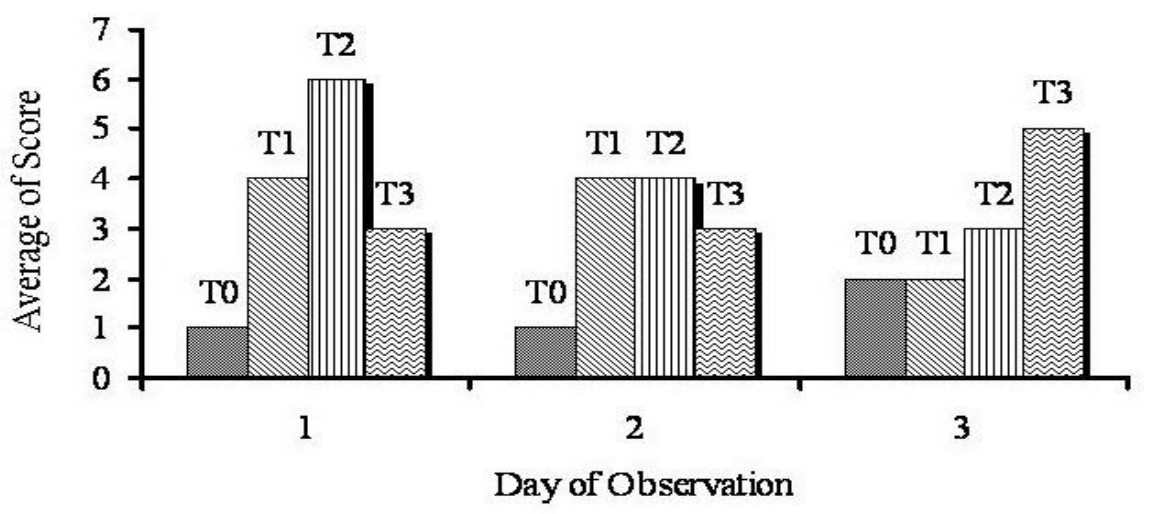

Figure 2.The graph of ferning of cervical mucus. T0 $=$ without Anredera cordifolia supplementation; TI = Anredera cordifolia supplementation two days before parturition; $\mathrm{T} 2=$ Anredera cordifolia supplementation two days before parturition; T3 = Anredera cordifolia supplementation two days before until two days after parturition.

production of saliva in the salivary glands. Saliva contains potassium which had the ability to form ferning. Ferning of saliva were found in T1, T2 and T3 because of estrogenic effects of the phytoestrogens in Anredera cordifolia. Therefore, ferning was formed.

Ferning score of cervical mucus in T0, T1, $\mathrm{T} 2$, and $\mathrm{T} 3$ in the first day were 1, 4, 6 and 3, respectively. In the second day were 1, 4, 4, 3 and the third day were 2,2, 3 and 5 respectively for T0, T1, T2 and T3 (Figure 2). The same as ferning of saliva, ferning of cervical mucus in T0 had the lowest average score of ferning. This was related to the treatments. T0 did not get Anredera cordifolia which contained phytoestrogens, consequently ferning of $\mathrm{T} 0$ has the lowest average score of ferning compared to other treatments. Phytoestrogens would give estrogenic effects if the levels of endogenous estrogen in the blood were low. In this period, phytoestrogens of Anredera cordifolia would form the ferning. Phytoestrogens would form an anti-estrogenic effect if endogenous estrogen in the blood increased. Sitasiwi (2009) stated that phytoestrogens had a structure that similar to endogenous estrogen, but it had two effects, namely estrogenic and anti-estrogenic effects.

Ferning of cervical mucus was found in T1, T2 and T3. Kesserii (1973) and Ax et al. (2000) stated that the appearance of ferning associated with levels of chlorine $(\mathrm{Cl})$ because chlorine had the ability to form ferning. An increased estrogen level in the blood would affect chlorine concentration. As a result, ferning could be found in the cervical and saliva mucus. However, the ferning of cervical mucus was determined by the concentration of sodium, while the saliva ferning was determined by the levels of potassium (Mardiati, 2007).

\section{CONCLUSION}

Anredera cordifolia (Ten.) Steenis supplementation could accelerate post partum oestrus in does which were characterized by post partum oestrus behavior, ferning of saliva and cervical mucus. The best treatment was T3 (four days Anredera cordifolia administration at 0.45 $\mathrm{g} / \mathrm{kg}$ of body weight/day). Further research was needed to find an optimal dose of Anredera cordifolia (Ten.) Steenis supplementation on uterine involution.

\section{REFERENCES}

Almatsier, S. 2004. Prinsip Dasar Ilmu Gizi. PT. Gramedia Pustaka Umum, Jakarta.

Astuti, S.M., A.M.M. Sakinah, B.M.R. Andayani, and A. Risch. 2011. Determination of saponin compound from Anredera cordifolia (Ten) Steenis plant (binahong) to potential treatment for several diseases. J. Agric. Sci. 3(4):224-232.

Ax, R. L., M. Dally, B.A. Didion, R.W. Lenz, C.C. Love, D.D. Varue, B. Hafez and M. E. Bellin. 2000. Cervical Mucus. In : B. Hafez, and E.S.E. Hafez (Eds.). Reproduction In Farm Animals. $7^{\text {th }}$ Ed.Lippincot Williams \& 
Wilkins, Philadelphia.

Ball, P.J.H. and A.R. Peters. 2004. Reproduction in Cattle Third Edition. Blackwell Publishing, Oxford.

Dewantiningrum, J. 2008. Perbedaan Pengaruh Clomiphene Citrate dan Letrozole terhadap Folikel, Endometrium dan Lendir Serviks Uji Klinik pada Wanita Infertil dengan Siklus Haid Tidak Teratur. Tesis. Universitas Diponegoro, Semarang.

Dewi, R.R., Wahyuningsih, and D.T. Widayati. 2011. Respon oestrus pada kambing peranakan ettawa dengan body condition score 2 dan 3 terhadap kombinasi implant controlled internal drug release jangka pendek dengan injeksi prostaglandin f2 alpha. J. Kedokteran Hewan 5(1):11-16.

Hardjopranjoto, S. 1995. Ilmu Kemajiran pada Ternak. Airlangga University Press. Surabaya.

Hernandez, J.A., F.I.F. Perez, C.H. Calleros and M.P. Martinez. 2013. Macroscopic morphometric analysis of genital organs of rabbit does with differing parturitions at 24 hours post-weaning. Int. J. Morphol. 31(3):991-996.

Kesserii, E. 1973. Assessment of the Rheology of Cervical Mucus. In: Elstein M, Moghissi S.K., Borth R. Editors. Cervical mucus in human reproduction. Copenhagen, Scriptor. pp.46-54.

Manoi, F., and Ballitro. 2009. Binahong (Anredera cordifolia) Sebagai Obat. Warta Penelitian dan Pengembangan Tanaman Industri 15(1):3-6.

Mardiati, S.M. 2003. Kadar Garam $\mathrm{Na}$ Lendir Serviks serta Kadar Garam $\mathrm{Na}$ dan $\mathrm{K}$ Lendir Mulut pada Berbagai Struktur Daun Pakis (Tes Ferning). Tesis. Program Pasca Sarjana, Universitas Diponegoro, Semarang.

Mardiati, S. M. 2007. Perbandingan Kadar Garam Natrium dan Kalium pada Tes Ferning Lendir Mulut. J. Sains dan Matematika (JSM) 15(1):5-7.

Menaarguez, M., L.M. Pastor and E. Odeblad. 2003. Morphological characterization of different human cervical mucus types using light and scanning electron microscopy. Human Reproduction 18(9):1782-1789.
Noonan, J.J., A.B. Schultze and E. F. Ellington. 1975. Changes in bovine cervical and vaginal mucus during the estrous cycle and early pregnancy. J. Anim. Sci. 41:1084-1089.

Nur, D. M. 2010. Perbedaan Kadar Vitamin C Pada Daun Binahong Segar Dan Ekstrak Daun Binahong (Anredera cordifolia (Ten.) Steenis). Tesis. Universitas Muhammadiyah Semarang, Semarang.

Samsudewa, D. and S.S. Capitan. 2011. Reproductive behaviour of timor deer (Rusa timorensis). Wartazoa 21(3) : 108-113.

Setiaji, A., Sutopo and E. Kurnianto. 2013. Growth analysis in rabbit using gompertz non-linear model. J. Indonesian Trop. Anim. Agric. 38 (2): 92-97.

Sitasiwi, A. J. 2009. Efek paparan tepung kedelai dan tepung tempe sebagai sumber fitoestrogen terhadap jumlah kelenjar endometrium uterus mencit (Mus musculus L.). Buletin Anatomi dan Fisiologi XVII (1) : 62-69.

Suharto, K. 2003. Penampilan Potensi Reproduksi Sapi Perah Friesian Holstein Akibat Pemberian Kualitas Ransum Berbeda dan Infusi Larutan Iodium Povidon 1\% Intra Uterin. Tesis. Program Pasca Sarjana, Fakultas Peternakan, Universitas Diponegoro, Semarang.

Syarfati, K. Eriani and A. Damhoeri. 2011. The potential of jarak cina (Jatropha multifida L.) secretion in healing new-wounded mice. Jurusan Biologi FMIPA, Universitas Syiah Kuala, Darussalam, Banda Aceh. J. Natural $11(1): 1-4$.

Tambing, S.N., M. Gazali and B. Purwantara. 2001. Pemberdayaan teknologi inseminasi buatan pada ternak kambing. Wartazoa 11(1):1-9.

Tarsono, Najamudin, Mustaring, Y. Duma, and Supriono. 2009. Performa litter kelinci induk lokal yang diberi pakan hijauan ubi jalar disuplementasi sejumlah konsentrat berbeda. J. Agroland 16 (1) : 78 - 84.

Wodzicka-Tomaszewska, M., I.K. Sutama, I.G. Putu and T.D. Chaniago 1991. Reproduksi, Tingkah Laku dan Produksi Ternak Indonesia. Penerbit Gramedia Pustaka Utama, Jakarta. 